\title{
B-Sitosterol of Red Dragon Fruit (Hylocereus Polyrhizus) And Its Response to Macrophage And Nitric Oxide
}

\author{
Sri Wahdaningsih, Subagus Wahyuono ${ }^{2 *}$, Sugeng Riyanto ${ }^{3}$, Retno Murwanti4
}

1. Departement of Pharmacy, Faculty of Medicine, Tanjungpura University, Pontianak, Kota Pontianak, of

2. Department of Pharmaceutical Biology Faculty of Pharmacy, Gadjahmada University, Skip Utara Yogyakarta Indonesia, 55281

3. Department of Pharmaceutical Chemistry Faculty of Pharmacy, Gadjahmada University, Skip Utara Yogyakarta Indonesia, 55281

4. Department of Pharmacology and Clinical Pharmacy Faculty of Pharmacy, Gadjahmada University, Skip Utara Yogyakarta Indonesia, 55281

\begin{tabular}{|c|c|}
\hline Info Article & ABSTRACT \\
\hline Submitted: $20-05-2020$ & Hylocerius polyrhizus has relatively big potency as natural antioxidant. \\
\hline Revised: $28-07-2021$ & The compound considered as antioxidant also has immunomodulatory \\
\hline Accepted: $20-09-2021$ & activity. This study showed isolation to identifying Hylocereus polyrhizus \\
\hline $\begin{array}{l}\text { *Corresponding author } \\
\text { Subagus Wahyuono }\end{array}$ & $\begin{array}{l}\text { peels active compounds to increase immune system of human body. The } \\
\text { methanol extracts were partitioned and fractionated. Petroleum ether } \\
\text { fraction active compounds were partitioned and purified using Preparative }\end{array}$ \\
\hline $\begin{array}{l}\text { Email: } \\
\text { subagusw_fa@ugm.ac.id }\end{array}$ & $\begin{array}{l}\text { Thin Layer Chromatography (PTLC). Active compound structures was } \\
\text { identificated with spectroscopy: UV, FT-IR, }{ }^{13} \text { CNMR, }{ }^{1} \mathrm{HNMR} \text {, DEPT and HSQC. }\end{array}$ \\
\hline & $\begin{array}{l}\text { The immunomodulatory activity was also tested. Based on the spectroscopic } \\
\text { data, the identified isolate was } \beta \text {-sitosterol. Macrophage cell activity and nitric } \\
\text { oxide showed that isolates at the highest concentrations of } 100 \mu \mathrm{g} / \mathrm{mL} \text { were } \\
\text { able to activate macrophage cells and enhance the production of nitric oxide. } \\
\text { Keywords: H. polyrhizus, } \beta \text {-sitosterol, macrophage, nitrit oxide }\end{array}$ \\
\hline
\end{tabular}

\section{INTRODUCTION}

Red dragon peels had better antioxidant activity than its flesh did (Wu et. al., 2006; Nurliyana et. al., 2010). Red dragon peels are rich of natural antioxidant compounds including flavonoids, phenolics, carotenoids, and anthocyanins. Furthermore, the peels contained pectin, anthocyanin, and other compounds like mannose, galacturonic acid, xylose, galactose, and rhamnose (Muhammad et al., 2014; Handayani and Rahmawati, 2012). Compounds that functioned as immunomodulator included alkaloid, polysaccharides, isoflavonoids, flavonoids, terpenoids, saponins, glucosides, fatty acids, tannins, steroids, and triterpenes (Wagner et. al., 1991; Parmar et. al., 1997; Roshan and Savitri, 2013). Wahdaningsih et. al. (2017) showed on the methanol extracts, ethyl acetate soluble fraction and ethyl acetate insoluble fraction contains total phenolics were $0.1994,0.0196$ and $0.4020 \mu \mathrm{gGAE} / \mathrm{g} H$. polyrhizus extract respectively and total flavonoids were 0.5139, 46.54 and $11.3811 \mu \mathrm{gQE} / \mathrm{g} H$. polyrhizus extract respectively (Wahdaningsih et al., 2017). The result also showed antioxidant activities were $241.19 \mu \mathrm{g} / \mathrm{mL}$, $8.34 \mu \mathrm{g} / \mathrm{mL}$, and $46.84 \mu \mathrm{g} / \mathrm{mL}$ respectively (Wahdaningsih et al., 2017). The antioxidant activities $H$. polyrhizus of isolated lupeol and of $\beta$-sitosterol were $2.952 .14 \pm 0.02 \mu \mathrm{g} / \mathrm{mL}$ and $5.636 .95 \pm 1.31 \mu \mathrm{g} / \mathrm{mL}$ respectively (Wahdaningsih et al., 2017).

Substance that can make an affect or change immune response in the body is called Immunomodulator. It can make an impact or change immune response in the body. Immune system of body occure an adaptive and innate immune with a complex system involving biochemical mechanism. The previous studies showed that red dragon fruit contains the active compound terpenoid lupeol which has immunomodulatory activity. However, the previous studies have not found active 
compounds from red dragon fruit peels which have macrophage phagocytic activity and nitric oxide enhancement. Therefore, in this study, the active compounds with immunomodulatory activities, particularly macrophage phagocytosis and nitric oxide, from the fruit peels were isolated and identified for their structures.

\section{MATERIALS AND METHODS Plant Materials}

The used sample was pericarp of red dragon fruits which taken from Bantul, Yogyakarta, Indonesia. It was taken from ripped dragon fruits, which were identified by all rounded red pericarp. The used fruits were $30.29 \mathrm{~kg}$. Of the total weight, the pericarp result was $7.17 \mathrm{Kg}(23.671 \%)$. The obtained simplicia of the pericarp was $800 \mathrm{~g}$ (11.158\%).

\section{Extraction, Fractionation, and Isolation}

Maceration process was done by dissolving $800 \mathrm{~g}$ of the simplicia in solvent with room temperature. The solvent used is methanol. After $24 \mathrm{~h}$, the filtrates were separated through filtration process using a Buchner funnel supported with a vacuum. The residue was re extracted with the same methods; it was done three times. The fractionation of petroleum ether-soluble fraction (2.0 grams) was done with Vacuum Liquid Chromatography (VLC). The stationary phase used is Silica Gel 60 in chromatography column. While the mobile phase used is and increasing gradient polarity system. The mobile phases ratio were petroleum ether (PE) : ethyl acetate [50mL PE], [49:1], [47.5:2.5], [45:5], [42.5:7.5], [40:10], [37.5:12.5], [35:15], [30:20], and [25:25]. There are 10 fractions analyzed using Thin Layer Chromatography (TLC) with ratio of petroleum ether : ethyl acetate (10:1). These fractions were sprayed with cerium sulfate reagent. Isolation process of target compounds was done by using Preparative Thin Layer Chromatography (PTLC). The stationary phase used is silica gel $\mathrm{PF}_{254}$, with $0.5 \mathrm{~mm}$ thickness, and the mobile phase ratio were petroleum ether : ethyl acetate $(10: 1)$. The isolation results were then filtered.

\section{Structure analysis with spectroscopy}

Structure analysis was done with spectroscopic data UV, Infrared spectroscopy (FTIR. Perkins Elmer 100), with 1 D and 2 D nuclear magnetic resonation (NMR, JEOL 500MHZ) for the isolated pure compounds.

\section{In vitro immunomodulatory activity test \\ Isolation of Macrophage Cell}

The laboratory rats were anesthetized by chloroform and then were dissected. The rats were

laid down on a surgery board. This study has obtained ethical clearance for research. Their abdominal skins were dissected and their peritoneum veils were cleaned with alcohol $70 \%$. Cool RPMI solution $(10 \mathrm{~mL})$ was injected into peritoneum cavity, waited until 3 min while slowly rolled. Removed the peritoneal fluid by pressing the internal organs with two fingers from peritoneum cavity; the tissue, chosen from nonfatty parts and far from gut, was aspirated with syringe. The aspiration material - contained syringes were put into an icy beaker glass. The suspensions were then put within centrifuge tubes. The aspirates were centrifuged at $4^{\circ} \mathrm{C}$ and 1,200 rpm for $10 \mathrm{~min}$. The supernatants were discarded; complete media $(3 \mathrm{~mL})$ were added to the obtained pellets. Then, cultured the counted cell suspensions by 24 well plates which each well was $200 \mathrm{~L}\left(5 \times 10^{5}\right)$ and the 24 well plates had been given the round coverslips. Incubated the cultured in a $\mathrm{CO} 25 \%$ incubator at $37^{\circ} \mathrm{C}$ for $30 \mathrm{~min}$. The complete media $(1 \mathrm{~mL})$ were added to each well and reincubated them for $2 \mathrm{~h}$. After that, washed the cells with RPMI twice, added with complete media $(1 \mathrm{~mL} /$ well), and reincubated until 24h (Wahdaningsih et al., 2020).

Test of Macrophage Phagocytic Activity with Latex Beads

Phagocytic capacity non-specific in vitro test was done by latex beads $(3 \mu \mathrm{m})$. The latex beads were suspended at became $2.2 \times 10^{7} / \mathrm{mL}$ concentration with phosphate-buffered saline. Isolates were added with some concentration in RPMI media $(400 \mu \mathrm{L})$ with control media DMSO solvent $(0.0025 \%)$. Then, removed the non phagocytosed particles by washing the cells three times with PBS, dried them at room temperatures, and fixated them with absolute methanol. The coverslips which had been dried then were stained with Giemsa $(20 \% \mathrm{~b} / \mathrm{v})$ for $30 \mathrm{~min}$ and used the distilled water to wash the coverslips. Then, gently lifted them from culture well plates and dried them at room temperature. The 100 cells which observed 
under the light microscope at 400x magnification were counted to percentage the cell phagocytosis latex particles. The 100 cells which observed under the light microscope at 400x magnification were counted to percentage the cell phagocytosis latex particles and replay the treatment three times (Wahdaningsih et al., 2018).

\section{Measurement of Nitric Oxid}

Sodium nitrite $(69 \mathrm{mg})$ was dissolved into Aqua Bidest $(100 \mathrm{~mL})$ to produce stock of nitrite standard solution $(2000 \mu \mathrm{M})$ and was stored at $-4^{\circ} \mathrm{C}$ and was protected from light. The solution of nitrite standard was prepared for the series of concentrations at the range of $0-100 \mu \mathrm{M}$. Then, put the solutions with various concentrations into 96multiwell plate, in duplo, at $100 \mu \mathrm{L}$ each. The same treatment was done for the incubated macrophages resulted from the macrophage isolation process; they were added into the well. Griess reagent $(100 \mu \mathrm{L})$ which consisting of Griess A $150 \mathrm{~mL}$ of acetic acid $30 \% \mathrm{v} / \mathrm{v}$ with $0.5 \mathrm{~g}$ of sulfanilate acid) and Griess B (20mL of Aqua bidestillata and $150 \mathrm{~mL}$ of glacial acetic acid $0.1 \mathrm{~g}$ of naphthyl ethylenediamine) was added with 1:1 comparison into each well. Then they were incubated for approximately $15 \mathrm{~min}$ at the room temperature and their absorbance was read with microplate reader at $595 \mathrm{~nm}$ (Titheradge, 1998).

\section{Data Analysis}

Shapiro-Wilk test can be used for analyzing the homogeneity and distribution of the phagocytosis data. The differences among the treatments showed in one-way Analysis of Variance (ANOVA) and Least Significant Difference (LSD) analysis at the 95\% level of confidence if the data were normally distributed and homogeneous.

\section{RESULTS AND DISCUSSION Identification of Isolated Compounds UV-Vis}

The identification of UV-Vis spectroscopy of the isolates dissolved in chloroform solvent showed the peak of UV-Vis spectra $\left(\lambda_{\text {maks }}\right)$ was at $282.4 \mathrm{~nm}$ of wavelength and 0.301 of absorbance. The UV-Vis spectra data showed that the molar absorptivity $(\varepsilon)$ was 62.70 .

FTIR (KBr)

The Fourier Transform Infrared (FT-IR) spectra informed the functional groups of isolated compounds. It showed hydroxyl group $(-\mathrm{OH})$ creating hydrogen bond on absorbance ribbon stretching at $3424 \mathrm{~cm}^{-1}$. The strong ribbon at 2937 and $2870 \mathrm{~cm}^{-1}$ indicated the stretching bond of aliphatic hydrocarbons (C-H). Isolated $\mathrm{C}=\mathrm{C}$ double bond showed on the weak absorbance at $1620 \mathrm{~cm}^{-1}$. The weak absorbance at 1464 and $1379 \mathrm{~cm}^{-1}$ showed bending vibration of $\mathrm{CH}_{2} \mathrm{CH}_{3}$ bonds, and the weak ribbon at $1056 \mathrm{~cm}^{-1}$ indicated stretching vibration of C-O bonds (Silvester and Webster, 2000; Pavia et al., 2001) (Figure 1).

Interpretation of mass spectrum

The data analysis of mass spectrum applying electron spray ionization (HR-ESI-TOFMS) pattern showed that the ion mass of isolated molecules at mass spectrum was $m / z \quad 413,3832[\mathrm{M}-\mathrm{H}]$ with $\mathrm{C}_{29} \mathrm{H}_{50} \mathrm{O}$ molecule formula and Double Bond Equivalent (DBE) $=5$ (Figure 2).

${ }^{13} \mathrm{C}-\mathrm{NMR}$

The isolate ${ }^{13} \mathrm{C}-\mathrm{NMR}$ spectrum indicated the 29 carbon atoms exist in a compound. The signal at $\delta_{c} 71.7$ ppm was the signal of C-3 bonding hydroxyl group $(-\mathrm{OH})$ showing higher chemical shift than other carbons in A ring of steroid core structure. The signal at $\delta_{\mathrm{c}} 140.9 \mathrm{ppm}$ and $\delta_{\mathrm{c} 121.8 \mathrm{ppm}}$ indicated the existence of olefinic carbons $(\mathrm{C}=\mathrm{C})$, C-5 and C-6, showing a chemical shift at a more deshelded region than other carbons in $\mathrm{B}$ ring of steroid. Gem-dimethyl carbons at $\delta \mathrm{c} 19.9 \mathrm{ppm}$ and $8 \mathrm{c} 18.8 \mathrm{ppm}$ were signal of C-26 and C-27.

1H-NMR

The interpretation of ${ }^{1} \mathrm{H}-\mathrm{NMR}$ spectra indicated characteristic signal of olefinic protons, proton $\mathrm{H}-6$, at $\delta_{\mathrm{H}} 5.28 \mathrm{ppm}$ chemical shift region. $\mathrm{H}-3$ protons of steroid A ring appearing at $\delta_{\mathrm{H}} 3.61$ ppm showing $-\mathrm{OH}$ groups. Strong signals of methyl group protons showed at the aliphatic region were proton $\mathrm{H}-18$ at $\delta_{\mathrm{H}} 0.61 \mathrm{ppm}$, proton $\mathrm{H}-19$ at $\delta_{\mathrm{H}} 0.94$ ppm, and proton $\mathrm{H}-21$ at $\delta_{\mathrm{H}} 0.85$ ppm chemical shift. Proton $\mathrm{H}-29$ appeared at $\delta_{\mathrm{H}} 0.78 \mathrm{ppm}$, and gemdimethyl protons of $\mathrm{H}-26$ and $\mathrm{H}-27$ appeared at $\delta_{\mathrm{H}} 0.72 \mathrm{ppm}$ and $\delta_{\mathrm{H}} 0.77 \mathrm{ppm}$ respectively.

DEPT 135

The complexity of absorbance peak could be analyzed with Distortionless Enhacement by Polarization Transfer (DEPT) 135 so it was possible to differentiate the signals of methyl $\left(-\mathrm{CH}_{3}\right)$, mehylene $\left(-\mathrm{CH}_{2}\right)$, and methine $(-\mathrm{CH})$ of a compound; the signal of $\mathrm{CH}_{3}$ and $\mathrm{CH}$ was positive while the signal of $\mathrm{CH}_{2}$ was negative (Syah, 2016). Each peak of mehylene was at $\delta_{c} 42.1 \mathrm{ppm}$ (C-4). 


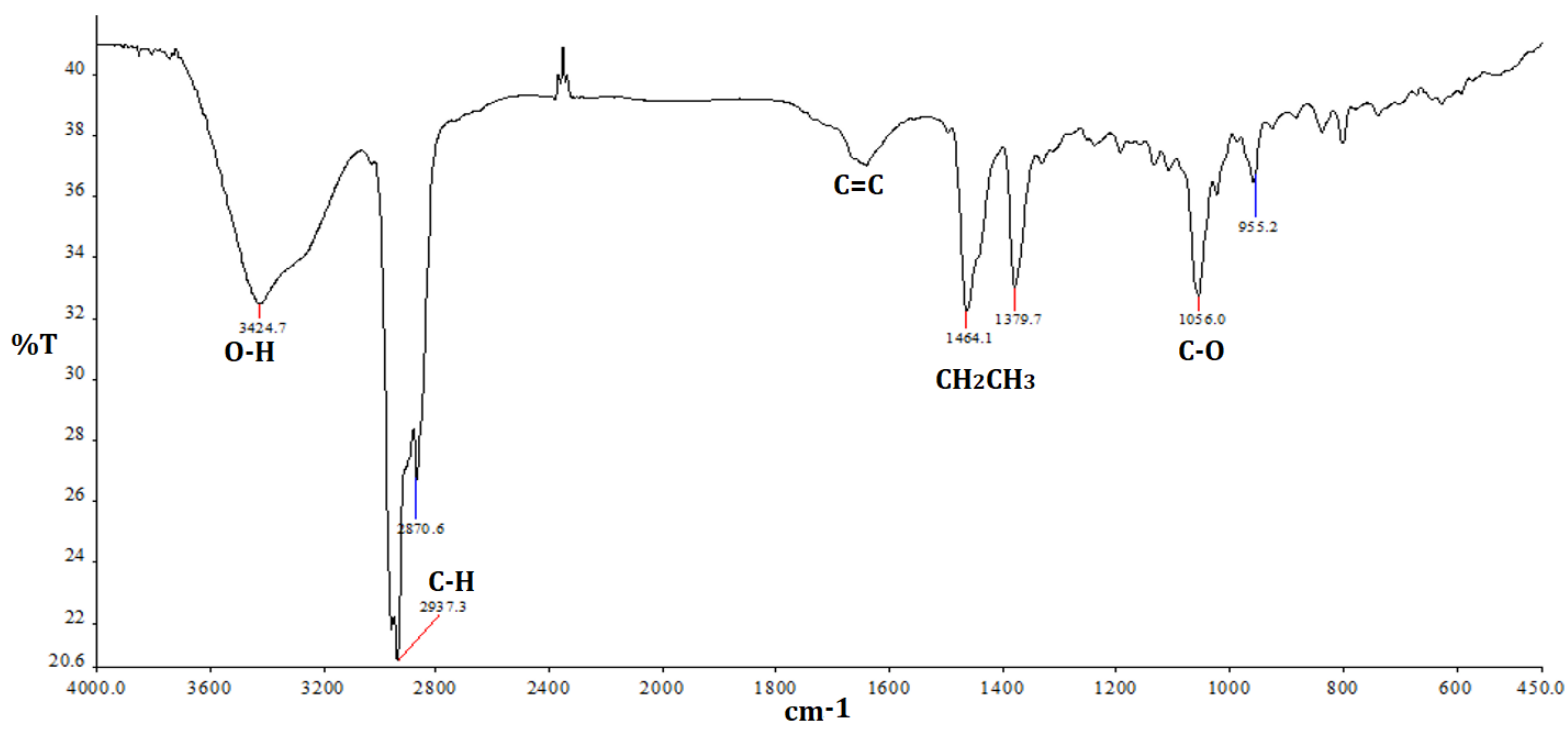

Figure 1. Isolate FT-IR Spectra in KBr Pellet

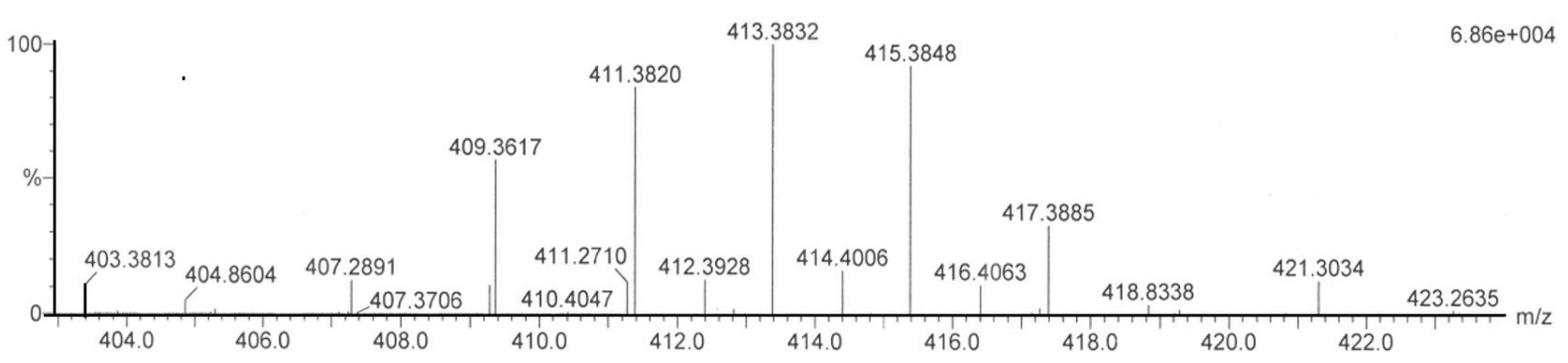

Figure 2. Isolate Mass Spectrum (HR-ESI-TOFMS)

The peaks of methine were at $\delta_{\mathrm{c}} 71.7 \mathrm{ppm}(\mathrm{C}-3), \delta_{\mathrm{c}}$ 121.8 ppm (C-6), $\delta_{c} 50.2$ ppm (C-9), $\delta_{c} 56.8$ ppm (C14) and $\delta_{c} 56.1 \mathrm{ppm}(\mathrm{C}-17)$. The peaks of mehylene

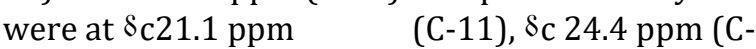
$23)$, and $\delta_{c} 23.1 \mathrm{ppm}(\mathrm{C}-28)$.

The peaks of methyl were at $\delta_{\mathrm{c}} 11.9 \mathrm{ppm}(\mathrm{C}-18), \delta_{\mathrm{C}}$ 19.4 ppm (C-19), $\delta_{\mathrm{c} 19.1} \mathrm{ppm}(\mathrm{C}-21), \delta_{\mathrm{c} 19.9} \mathrm{ppm}$ (C-26), $\delta_{\mathrm{C}} 18.8 \mathrm{ppm}(\mathrm{C}-27)$ and $\delta_{\mathrm{c}} 12.1 \mathrm{ppm}(\mathrm{C}-29)$. The peaks of mehylene were at $\delta_{\mathrm{C}} 37.3 \mathrm{ppm}(\mathrm{C}-1)$,

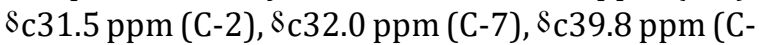
12), $\delta_{\mathrm{C}} 26.1 \mathrm{ppm}(\mathrm{C}-15), \delta_{\mathrm{C}} 28.3 \mathrm{ppm}(\mathrm{C}-16)$, and $\delta_{\mathrm{C}}$ $33.8 \mathrm{ppm}(\mathrm{C}-22)$. Furthermore, the peaks of methine were also at $\delta_{C} 32.0 \mathrm{ppm}(\mathrm{C}-8), \delta_{\mathrm{C}} 36.3$ ppm (C-20), \&c 45.9 ppm (C-24) and \&c 29.2 (C-25). Based on the interpretation of DEPT 135, isolate 2 had 9 methine $(\mathrm{CH})$ atoms, 11 mehylene $\left(\mathrm{CH}_{2}\right)$ atoms, and 6 methyl $\left(\mathrm{CH}_{3}\right)$ atoms.

HSQC

Hetero Nuclear Single Quantum Coherence (HSQC) spectrum showed connectivity between signals of proton core and carbon. Proton H-6 with signal at $\delta_{\mathrm{H}} 5.28 \mathrm{ppm}$ gave cross peak with signal of C-6 at $\delta_{\mathrm{C}} 121.8 \mathrm{ppm}$, indicating that proton $\mathrm{H}-6$ was bonded with C-6 atom. Proton $\mathrm{H}-18$ with signal at $\delta_{\mathrm{H}} 0.61$ ppm gave cross peak with signal of $\mathrm{C}-18$ at $\delta_{\mathrm{C}} 11.9 \mathrm{ppm}$, indicating that proton $\mathrm{H}-18$ was bonded with $\mathrm{C}-18$ atom. In addition, proton $\mathrm{H}-19$ with signal at $\delta_{\mathrm{H}} 0.94 \mathrm{ppm}$ gave cross peak with signal of C-19 at $\delta_{\mathrm{C}} 19.4 \mathrm{ppm}$, indicating that proton H-19 was bonded with $\mathrm{C}-19$ atom. Proton $\mathrm{H}-21$ with signal at $\delta_{\mathrm{H}} 0.85 \mathrm{ppm}$ gave cross peak with signal of C-21 at $\delta_{\mathrm{C}} 19.1 \mathrm{ppm}$, indicating that proton H-21 was bonded with C-21 atom. Proton H-26 with signal at $\delta_{\mathrm{H}} 0.72 \mathrm{ppm}$ gave cross peak with signal of C-26 at $\delta_{\mathrm{C}} 19.9 \mathrm{ppm}$, indicating that proton H-26 was bonded with C-26 atom. Proton H-27 with signal at $\delta_{\mathrm{H}} 0.77 \mathrm{ppm}$ gave cross peak with signal of $\mathrm{C}-27$ at $\delta_{\mathrm{C}} 18.8 \mathrm{ppm}$, indicating that proton $\mathrm{H}-27$ was bonded with $\mathrm{C}-27$ atom. Proton $\mathrm{H}-29$ with signal at $\delta_{\mathrm{H}} 0.78 \mathrm{ppm}$ gave cross peak with signal of C-29 at $\delta_{\mathrm{C}} 12.1 \mathrm{ppm}$, indicating that proton H-29 was bonded with C-29 atom (Table I). 
Table I. Data of Isolate NMR Spectra

\begin{tabular}{|c|c|c|c|c|c|c|}
\hline \multirow{2}{*}{ Position C } & \multicolumn{2}{|c|}{ Chemical shift (ppm) isolate 2} & \multirow{2}{*}{ DEPT } & \multirow{2}{*}{ HSQC } & \multicolumn{2}{|c|}{ Chemical shift (ppm) $\beta$-sitosterol* } \\
\hline & ${ }^{13} \mathrm{C}-\mathrm{NMR}$ & 1H-NMR & & & 13C-NMR & 1H-NMR \\
\hline 1 & 37.3 & & $\mathrm{CH}_{2}$ & & 37.5 & \\
\hline 2 & 31.5 & & $\mathrm{CH}_{2}$ & & 31.9 & \\
\hline 3 & 71.7 & 3.61 & $\mathrm{CH}$ & & 72.0 & 352 \\
\hline 4 & 42.1 & & $\mathrm{CH}_{2}$ & & 42.5 & \\
\hline 5 & 140.9 & & & & 140.9 & \\
\hline 6 & 121.8 & 5.28 & $\mathrm{CH}$ & H-6 & 121.9 & 5.35 \\
\hline 7 & 32.0 & & $\mathrm{CH}_{2}$ & & 32.1 & \\
\hline 8 & 32.0 & & $\mathrm{CH}$ & & 34.2 & \\
\hline 9 & 50.2 & & $\mathrm{CH}$ & & 50.3 & \\
\hline 10 & 34.0 & & & & 36.7 & \\
\hline 11 & 21.1 & & $\mathrm{CH}_{2}$ & & 21.3 & \\
\hline 12 & 39.8 & & $\mathrm{CH}_{2}$ & & 39.9 & \\
\hline 13 & 42.4 & & & & 42.6 & \\
\hline 14 & 56.8 & & $\mathrm{CH}$ & & 56.9 & \\
\hline 15 & 26.1 & & $\mathrm{CH}_{2}$ & & 26.3 & \\
\hline 16 & 28.3 & & $\mathrm{CH}_{2}$ & & 28.5 & \\
\hline 17 & 56.1 & & $\mathrm{CH}$ & & 56.3 & \\
\hline 18 & 11.9 & 0.61 & $\mathrm{CH}_{3}$ & $\mathrm{H}-18$ & 12.0 & 0.68 \\
\hline 19 & 19.4 & 0.94 & $\mathrm{CH}_{3}$ & $\mathrm{H}-19$ & 19.0 & 1.01 \\
\hline 20 & 36.3 & & $\mathrm{CH}$ & & 38.2 & \\
\hline 21 & 19.1 & 0.85 & $\mathrm{CH}_{3}$ & $\mathrm{H}-21$ & 19.2 & 0.92 \\
\hline 22 & 33.8 & & $\mathrm{CH}_{2}$ & & 34.2 & \\
\hline 23 & 24.4 & & $\mathrm{CH}_{2}$ & & 26.1 & \\
\hline 24 & 45.9 & & $\mathrm{CH}$ & & 46.1 & \\
\hline 25 & 29.2 & & $\mathrm{CH}$ & & 29.4 & \\
\hline 26 & 19.9 & 0.72 & $\mathrm{CH}_{3}$ & H-26 & 20.1 & 0.81 \\
\hline 27 & 18.8 & 0.77 & $\mathrm{CH}_{3}$ & $\mathrm{H}-27$ & 19.6 & 0.83 \\
\hline 28 & 23.1 & & $\mathrm{CH}_{2}$ & & 23.3 & \\
\hline 29 & 12.1 & 0.78 & $\mathrm{CH}_{3}$ & H-29 & 12.2 & 0.84 \\
\hline
\end{tabular}<smiles>CCC(CCC(C)C1CCC2C3CC=C4CC(O)CCC4(C)C3CCC12C)C(C)C</smiles>

Figure 3. Chemical Structure of $\beta$-sitosterol (isolate)

Based on the data interpretation of UV, FTIR, MS, ${ }^{13}$ C-NMR, ${ }^{1} \mathrm{H}-\mathrm{NMR}$, DEPT 135 and HSQC spectra, it was concluded that the isolate was $\beta$ sitosterol compound and its chemical formula is $\mathrm{C}_{29} \mathrm{H}_{50} \mathrm{O}$ (Figure 3).

$\beta$-sitosterol had been reported to have activities of anti-inflammatory, antipyretic, antiarthritic, antiulcer, spermatogenesis-inhibitory, body immune system modulation, and carcinogen development reduction of colon cancer (Patra et al., 2010). The isolate known as $\beta$-sitosterol was able to improve lymphocyte proliferation activity; this corresponded to the study of Saeidnia et al., (2014). Moreover, $\beta$ sitosterol could stimulate antioxidant enzymes by activating estrogen receptors, and enhancing the NK cells, blood mononuclear cells, and pig dendritic cells (Saeidnia etal., 2014; Fraile etal., 2012). 


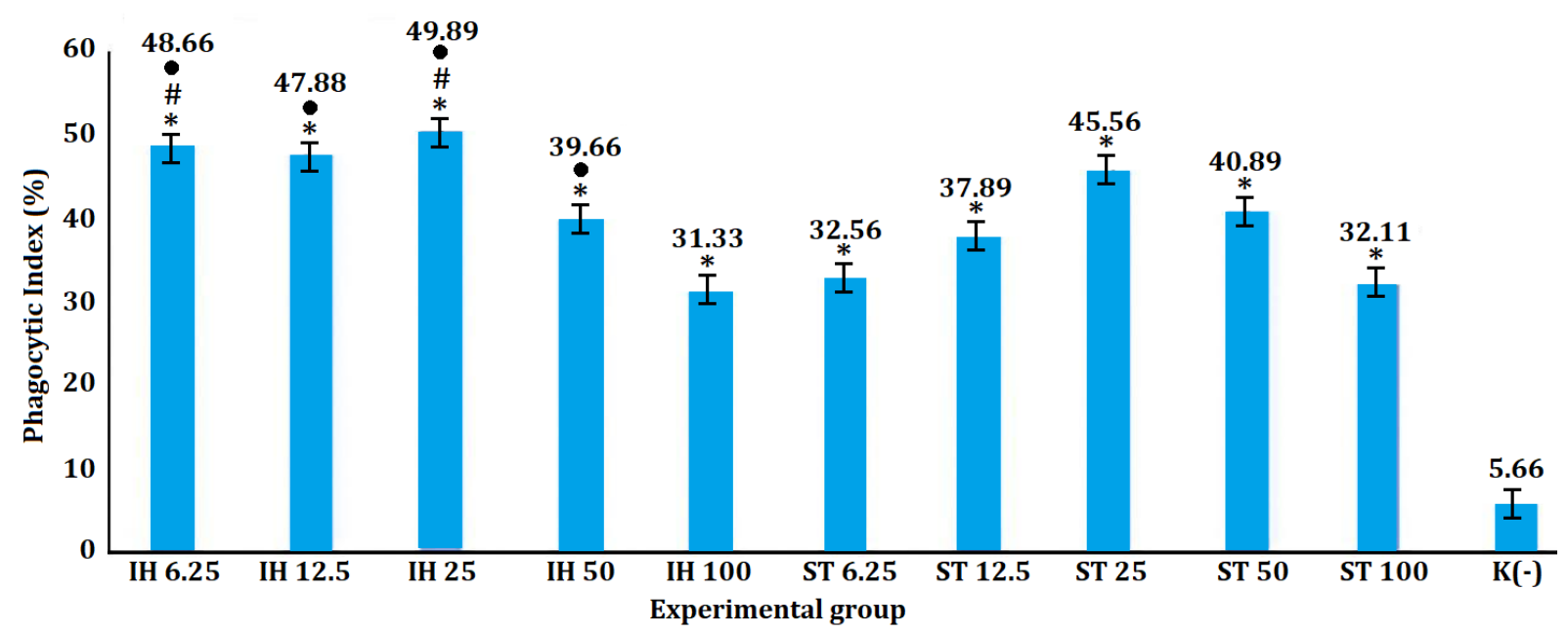

Figure 4. Percentage of Isolate Phagocytic Capacity (IH)

Remarks: $n=1$; Average SD \pm (Average \pm SD of three independent experiments); ${ }^{*}=$ Significantly different from control media (-); \# = Significantly different from ST; • = Significantly different from IH 100; IH = Isolates with concentrations of $6.25 ; 12.5 ; 25 ; 50 ; 100 \mu \mathrm{g} / \mathrm{mL}$; ST= Commercial product with Phyllanthus niruri extract as the active component with concentrations of $6.25 ; 12.5 ; 25 ; 50 ; 100 \mu \mathrm{g} / \mathrm{mL}$ K $(-)=$ Control media

Through AhR receptors, sitosterol influenced the development activity of spleen dendritic cells; dendritic cells secreted IL-12, and through IL-12, the cells activated $\mathrm{T}$ lymphocytes to produce IFN $\gamma$ (Xuan et al., 2010; Esser et al., 2009).

The In vitro immunomodulatory activity test of the isolated compounds was done using the method of leijh et al., (1986). Live macrophages that were isolated from experimental animals, laboratory rats, were used. The macrophages were the main phagocytic cells functioning to fight against pathogens through phagocytic mechanism both as innate immune response and adaptive immune response. Macrophages functioned as Antigen Presenting Cells (APC). In this study, macrophages from peritoneum cavity of the rats were isolated. The cavity was an abdominal cavity containing fluid; it was the place of immune cells like macrophages, $\mathrm{B}$ cells, and $\mathrm{T}$ cells (Ray and Dittel, 2010).

Based on the statistical analysis, isolates with concentrations of 100, 50, 25, 12.5 and $6.25 \mu \mathrm{g} / \mathrm{mL}$ were able to activate macrophages higher than control media did. The phagocytic index was the capacity of active macrophages phagocytosing latex. Based on the ANOVA analysis at the $95 \%$ level of confidence $(\mathrm{P}<0.05)$, the phagocytic index of isolates with concentration of $100,50,25,12.5$ and $6.25 \mu \mathrm{g} / \mathrm{mL}$ was significantly different form of the control media. The best isolate concentration used for immunomodulatory action was $25 \mu \mathrm{g} / \mathrm{mL}$ because at that concentration had the highest phagocytic capacity and phagocytic index. This is indicated through a graph of the phagocytic capacity and phagocytic index percentage of the isolate showed in Figure 4 and 5.

The capacity of macrophages to phagocytose indicated an improved immune system in either removing or killing pathogens. Isolates improved the phagocytic activities of macrophages to latex better than commercial product with Phyllanthus niruri extract as the active component did. The improvement of macrophage number and its activities in eating latex after isolate addition showed more positive activity than of the control media. This indicated that isolates had potential to give immunomodulatory effects (Figure 4 and 5)

The data showed that isolates had the highest phagocytic index (1.87) at a concentration of $25 \mu \mathrm{g} / \mathrm{mL}$, and Commercial product with Phyllanthus niruri extract as the active component had the highest phagocytic index (1.80) at a concentration of $25 \mu \mathrm{g} / \mathrm{mL}$. Based on Wagner (1985), the phagocytic index smaller than 1.2 indicated zero immunostimulant effects. The index between 1.3 and 1.5 showed medium immunostimulant effects; the index higher than 1.5 showed strong immunostimulant effect. 


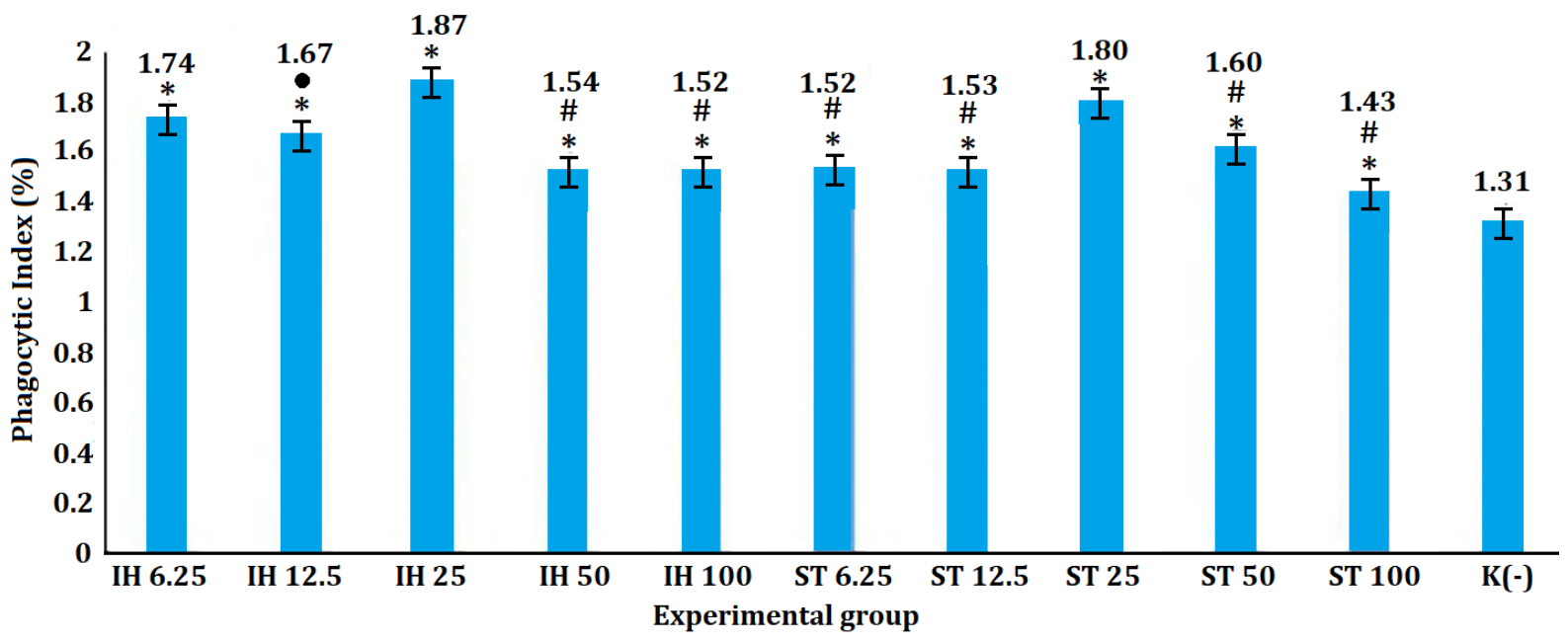

Figure 5. Isolate Phagocytic Index (IH)

(Remarks: $\mathrm{n}=1$; Average $\mathrm{SD} \pm$ (Average \pm SD of three independent experiments); ${ }^{*}=$ Significantly different from control media (-); \# = significantly different from IH 25 and IH 6.25; • = Significantly different from IH 25; IH = Isolates with concentrations of $6.25 ; 12.5 ; 25 ; 50 ; 100 \mu \mathrm{g} / \mathrm{mL}$ ST $=$ Commercial product with Phyllanthus niruri extract as the active component with concentrations of $6.25 ; 12.5 ; 25 ; 50 ; 100 \mu \mathrm{g} / \mathrm{mL} ; \mathrm{K}(-)=$ Control media

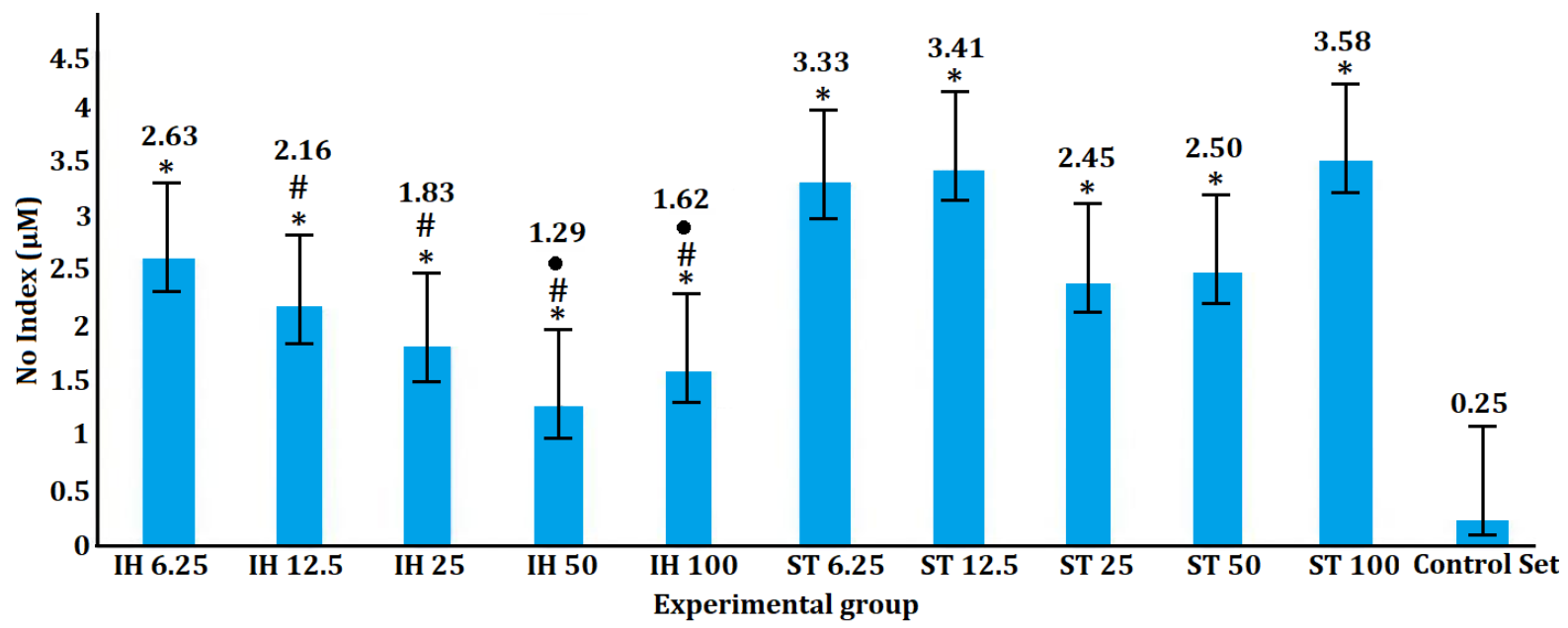

Figure 6. Effects of Isolate (IH) addition to NO production

(Remarks: $\mathrm{n}=1$; Average SD \pm (Average $\pm \mathrm{SD}$ of three independent experiments); ${ }^{*}=$ Significantly different from control cells; \# = significantly different from ST; $\bullet=$ Significantly different from IH 6.25 ; IH = Isolate with concentrations of $6.25 ; 12.5 ; 25 ; 50 ; 100 \mu \mathrm{g} / \mathrm{mL}$; ST= Commercial product with Phyllanthus niruri extract as the active component with concentrations of $6.25 ; 12.5 ; 25 ; 50 ; 100 \mu \mathrm{g} / \mathrm{mL}$ )

Isolates were able to influence the phagocytic index of macrophages to fight against and eliminate pathogens that attacked the body. The effect of isolates with concentrations of $6.25 \mu \mathrm{g} / \mathrm{mL}$, $12.5 \mu \mathrm{g} / \mathrm{mL}, 25 \mu \mathrm{g} / \mathrm{mL}, 50 \mu \mathrm{g} / \mathrm{mL}, 100 \mu \mathrm{g} / \mathrm{mL}$ were considered adequately strong due to the phagocytic index higher than 1.5. The ability of active macrophage cells to phagocytose latex is measured by the phagocytic index. The immune system's ability to eliminate or kill infections was strengthened by macrophages' phagocytic capacity. An increase in phagocytic index can lead to an increase in phagocytic capacity, resulting in a stronger immunostimulant effect. 


\section{Relationship between Phagocytic Index and Nitric Oxide (NO) Concentration}

Macrophage phagocytic activity of treatment groups with isolates and Commercial product with Phyllanthus niruri extract as the active component were relatively higher than that with control cells so that the nitric oxide (NO) production increased (Figure 6). NO was secreted by macrophages for phagocytosis. During the phagocytosis process, NO and macrophage lysosome work together to kill pathogens including bacteria, fungus, and viruses. Despite significant phagocytic activity, NO was able to cause cell damage in both the cells that create it and the cells around it, resulting in a reduction in NO concentration (Abbas et al., 2012). According to Hartini et al. (2014), The chemical composition of the samples may result in high macrophage phagocytic activity without excessive NO generation, preserving immune cell activities by protecting macrophages from excessive phagocytic activity. The excessive $\mathrm{NO}$ generation may increase the activity of the guanylate cyclase enzyme, which may have undesirable consequences such as protein induction, stress, DNA damage (Devlin, 2002).

The activation of NO production of rats treated with positive control (ST) and different isolate treatments was significantly different from that of rats with control cells. The activation of NO production of rats with preparation at concentration of $6.25 \mu \mathrm{g} / \mathrm{mL}$ is same with that of with positive control (ST). This releaved that both of them were potential for immunomodulatory effects. The activation of NO production indicated active phagocytes, where phagocytosis is an indication of improved immune system in either removing or killing pathogens. The ability of active macrophage cells to phagocytose latex is measured by the ohagoctic index. The immune system's ability to eliminate or kill infections was strengthened macrophages phagocytic capacity.

\section{CONCLUSION}

The identification of chemical structure of isolated compounds showed that the isolates were $\beta$-sitosterol. The result of immunomodulatory activity test using isolates at concentrations of 100 $\mu \mathrm{g} / \mathrm{mL}, 50 \mu \mathrm{g} / \mathrm{mL}, 25 \mu \mathrm{g} / \mathrm{mL}, 12.5 \mu \mathrm{g} / \mathrm{mL}$ and 6.25 $\mu \mathrm{g} / \mathrm{mL}$ revealed significant differences between the control group of media and the treatment group of isolates and control cells, indicating that isolates and control cells can increase macrophage phagocytic activity and nitric oxide production.

\section{REFERENCES}

Esser, C., Rannug, A., Stockinger, B., 2009. The aryl hydrocarbon receptor in immunity. Trends in Immunology, 30: 447-454.

Fraile, L., Crisci, E., Cordoba, L., Navarro, M. A., Osada, J., and Montoya, M., 2012. Immunomodulatory properties of betasitosterol in pig immune responses. Int. Immunopharmacology, 13: 316-321.

Handayani, P.A., and Rahmawati, A., 2012. Pemanfaatan Kulit Buah Naga (Dragon Fruit) sebagai Pewarna Alami Makanan Pengganti Pewarna Sintetis. J. Bahan Alam Terbarukan 1.

Leijh, P.C.J., Furth, R.V., and swet, T.L.V., 1986. in vitro determination of phagocytosis and intracellular killing by polymorphonuclear and mononuclear phagocytes dalam Weir, D.M., Cellular immunology, Vol 2., backwell scientific publication, London.

Muhammad, K., Mohd. Zahari, N.I., Gannasin, S.P., Mohd. Adzahan, N., Bakar, J., 2014. High methoxyl pectin from dragon fruit (Hylocereus polyrhizus) peel. Food Hydrocoll, 42: 289-297.

Nurliyana, R., Syed Z. I., Mustapha S. K., Aisyah, M. R., and Kamarul R. K., 2010. Antioxidant study of pulp and peel dragon fruits: a comparative study. Int. Food. Res. J, 17: 365-375.

Parmar, V.S., Jain, S.C., Bisht, K.S., Jain, R., Taneja, P., Jha, A.,Tyagi, O.D., Prasad, A.K., Wengel, J., Olsen, C.E., and Boll, P.M., 1997. Phytochemistry of the genus Piper. Phytochemistry, 46: 597-673.

Ray, A and Dittel, B.N., 2010. Isolation of mouse peritoneal cavity cells. Journal of Visualized Experiments, 35: 1-3.

Roshan, N. and Savitri. P., 2013. Review on Chemical Constituens and Parts of Plants as Immunomodulators. Research Journal of Pharmaceutical Biological and Chemical Sciences, 4: 76-89.

Saeidnia, S., Manayl, A., Gohari, A. R., and Abdollahi, M., 2014. The Story of beta - sitosterol- A Review. European Journal of Medicinal Plants, 4: 590-609.

Silverstein. R.M., and Webster, F.X., 2000. Spectrometric identification of organic 
compounds. 60th edn. John Wiley and Sons. Inc. New York.

Wagner, H and Jurcic, K., 1991. Assay for Imunomodulation and Effect on Mediators of Inflamation dalam Dey PM and Harborne JB editor. Methode in plants biochemistry; assay for bioactivity. Vol. VI. Academic Press.

Wahdaningsih, S., Wahyuono, S., Riyanto, S., Murwanti, R., 2017. The radical scavenging activity of 2-2' diphenyl -1- picrylhydrazil (dpph) on the methanol extracts and ethyl acetate fractions of red dragon fruit peel (Hylocereus polyrhizus (F.A.C.Weber) Britton dan Rose). International Journal of Phytomedicine. Vol 9 (1).

Wahdaningsih, S., Wahyuono, S., Riyanto, R and Murwanti R., 2017. Penetapan Kadar Fenolik Total dan Flavonoid Total Ekstrak Metanol dan Fraksi Etil Asetat Kulit Buah Naga Merah (Hylocereus polyrhizus (F.A.C.WEBER) BRITTON DAN ROSE). PHARMACONJurnal Ilmiah Farmasi UNSRAT. Vol. 6 (3): 295-301.

Wahdaningsih, S., Wahyuono, S., Riyanto, R and Murwanti R., 2018. Antioxidant Activity of Red Dragon Fruit Peel (Hylocereus polyrhizus (F.A.C.Weber) Britton and Rose)
Isolates Using DPPH Method. Asian J. Pharm Clin Res, Vol 11 (1): 124-128.

Wahdaningsih, S., Wahyuono, S., Riyanto, R and Murwanti R., 2018. In Vitro Test of Macrophage Phagocytic Activity of Extracts and Fractions of Red Dragon Fruit Peel (Hylocereus polyrhizus (F.A.C.Weber) Britton and Rose). Dhaka Univ.J. Pharm. Sci. 17 (2): 161-165.

Wahdaningsih. S., Wahyuono, S., Riyanto $\mathrm{R}$ dan Murwanti R., 2020. Terpenoid-lupeol of Red Dragon Fruit (Hylocereus polyrhizus) and Its Immunomodulatory Activity. Pak. J. Pharm. Sci. 33(2) : 505 - 510

Woronzoff-Dashkoff, K.K., 2002. The WrightGiemsa stain: secrets revealed. Clinics in laboratory medicine, 22: 15-23.

Wu, L., Hsu, H.-W., Chen, Y.-C., Chiu, C.-C., Lin, Y.-I., Ho, J.A., 2006. Antioxidant and antiproliferative activities of red pitaya. Food Chem, 95: 319-327.

Xuan, N. T., Shumilina, E., Qadri, S. M., Gotz, F., Lang, F., 2010. Effect of Thymoquinon on mouse dendritic cells. Cell Physiol Biochem, 25: 307-314. 